\title{
Root tuber of Tacca leontopetaloides L. (kunze) for food and nutritional security
}

\author{
Ogbonna $\mathrm{AI}^{1 *}$, Adepoju $\mathrm{SO}^{2}$, Ogbonna CIC ${ }^{1}$, Yakubu $\mathrm{T}^{1}$, Itelima $\mathrm{JU}^{1}$, Dajin $\mathrm{VY}^{1}$ \\ ${ }^{1}$ University of Jos, Plateau State, Nigeria \\ ${ }^{2}$ Forestry Research Institute of Nigeria (FRIN), Ibadan, Nigeria
}

\begin{abstract}
Tacca leontopetaloides L. (Kunze) is a wild perennial herbaceous and underutilized tuber crop. This study was aimed at analyzing quantitatively the tuber starch of $T$. leontopetaloides L. (Kunze) collected in the wild from Angwan Zam and Ntuer in Shendam Local Government Area (L.G.A) of Plateau State Nigeria for the presence of nutritional and anti-nutritional components. The proximate composition, elemental analyses and phytochemical composition of the tuber starch carried out revealed the presence of moisture, $8.66 \%$, crude protein, $6.79 \%$, crude fibre, $5.44 \%$, crude fat, $0.51 \%$, ash, $0.41 \%$, and NFE (total carbohydrate), $78.19 \%$. The elemental analysis of $T$. leontopetaloides indicated presence of some trace elements including sodium, $34.71 \mathrm{mg} / 100 \mathrm{~g}$, potassium, $40.18 \mathrm{mg} / 100$ $\mathrm{g}$, calcium, $0.25 \mathrm{mg} / 100 \mathrm{~g}$, magnesium, $1.40 \mathrm{mg} / 100 \mathrm{~g}$, iron, $1.37 \mathrm{mg} / 100 \mathrm{~g}$, zinc, $1.64 \mathrm{mg} / 100 \mathrm{~g}$, manganese, $0.72 \mathrm{mg} / 100 \mathrm{~g}$, copper, $0.68 \mathrm{mg} / 100 \mathrm{~g}$ and phosphorus, $0.06 \mathrm{mg} / 100 \mathrm{~g}$. The results of antinutrient composition of T. Ieontopetaloides revealed the presence of tannins, $2.50 \mathrm{mg} / 100 \mathrm{~g}$, Phytate, $49.77 \mathrm{mg} / 100 \mathrm{~g}$, oxalate, $15.51 \mathrm{mg} / 100 \mathrm{~g}$, cyanide, $0.18 \mathrm{mg} / 100 \mathrm{~g}$, alkaloids, $42.90 \mathrm{mg} / 100 \mathrm{~g}$, saponins, $14.67 \mathrm{mg} / 100 \mathrm{~g}$ and flavonoids, $1.46 \mathrm{~m} \mathrm{~g} / 100 \mathrm{~g}$. It was observed that steeping in water for sometimes had effects on the concentration of the anti-nutritional components. This in effect presents the tuber crop a good candidate as food source for humans in a developing country like Nigeria.
\end{abstract}

Keywords: Proximate composition, Anti-nutritional, Tacca leontopetaloides, Root tuber, Phytochemical composition. Accepted on 31 January, 2017

\section{Introduction}

Root and tuber crops provide a substantial part of the world food supply and are also an important source of animal feed and industrial products. On a global basic, approximately $45 \%$ of root and tuber crop production is consumed as food, with the remainder used as animal feed or for industrial processing for products such as starch, distilled spirit, alcohol and fermented beverages including beer and a range of minor products [1].

Millions of people in many developing countries do not have enough food to meet their daily requirements and many more are deficient in one or more micronutrients. In many cases rural communities depend on wild resources including wild edible plants to meet their food needs in periods of food shortage [1].

The diversity in wild species offers variety in the diet and contributes to household food security. India hold rich genetic diversity in tropical root and tuber crops particularly aroids yams and several minor tuber crops.

Wild edible tuber species are an important source of food in India and other parts of the world and have a significant place in the dietary habits of small and marginal farm families and forest devilling communities during periods of food scarcity [2]. An edible tuber not only enriches the diet of the people but also possesses medicinal properties. Many tropical tuber species are used in the preparation of stimulants, toning, carminatives and expectorants. These properties need to be documented to validate, quantify and spread this valuable knowledge [3].

According to Aberoumand and Deokule [4] despite the fact that measures have being taken to boost food production by conventional agricultural activities, there is the need to exploit the vast number of unconventional plants resources that exist in the wild. Akubugwo et al. [5] reported that many of such plants have been identified but lack of data on their chemical composition has limited the prospects of their utilization. Proximate analysis of some wild fruits and seeds indicate that they could be good sources of nutrients for man and livestock [6]. The exploration of indigenous wild food plant is one of the measures that could be taken to avoid hunger and malnutrition. Studies have shown that most rural dwellers depend largely on some of these edible wild plants to meet up with shortages in nutrients like minerals, proteins, lipids, and vitamin A [7].

Apart from the nutritional content of these wild plants, some are known to contained high levels of anti-nutritional components which could be toxic to the body, hence acting as threat to the health and well-being of an individual when consumed. Therefore some knowledge of the nutritional status and the toxic levels of indigenous edible wild plants are imperative in order to encourage their cultivation and consumption [8].

Tacca leontopetaloides (L.) Kuntze is a species of flowering plant from the family Taccaceae. It is commonly known as Polynesian arrow-root (English) or Amura (Hausa) and is a 
Citation: Ogbonna AI, Adepoju SO, Ogbonna CIC, et al. Root tuber of Tacca leontopetaloides L. (kunze) for food and nutritional security. Microbiology: Current Research 2017;1(1):7-13.

wild perennial herb. The plant originated from Malaysia and pacific Islands [9], but is now distributed from western Africa through Southeast Asia to northern Australia. The tubers were known to be a staple foodstuff in Polynesia and also were used as a source of starch.

In Nigeria, the plant is more wild spread in the middle belt [10] and in the south western states. The plant still remains in the wild and is under-utilized in Nigeria. It is found in solitary forms on open fields or under the shade of trees or hill tops. In Plateau State, the tubers are found to be a delicacy to the people of Shendam, Langtang and other members of lower Plateau and are eaten especially when other staple foods are scarce. The tubers are believed to be poisonous and contain a bitter principle, Taccalin and toxic saponins [11]. Ruminants rapidly die as soon as they consume the peels of these tubers. Aside the nutritional content of this plant, it is believed to contain some levels of anti-nutrients which could be toxic to the human body, thereby acting as threat to the health of an individual if taken. However, Caddick et al. [11] reported that the poisonous component of the tubers could be removed by soaking, washing and rinsing repeatedly in clean water before being processed for food.

Despite the fact that this tuberous crop is gaining acceptance among people of North Central of Nigeria, little or no information about the anti-nutritional composition of $T$. leontopetaloides plant is known. In addition, consumers may face the risk of toxicity due to improper processing.

The present study was then designed to evaluate the nutritional and anti-nutritional composition of Tacca leontopetaloides in order to ascertain it's suitability for use as food to man.

\section{Materials and Methods}

\section{Source of experimental root tubers}

The freshly harvested wild Polynesian arrowroot, Tacca leontopetaloides tubers used for the experiments were obtained from Angwan Zam and Ntuer in Shendam local government area (L.G.A) Plateau State Nigeria in October 2014. These tuberous materials were collected randomly from the wild.

\section{Preparation of the polynesian arrowroot starch samples}

The method for cassava (Manihot $\mathrm{sp}$ ) starch preparation of [12] was adopted with slight modification for the preparation of starch. These include manual peeling, washing (in clean water), cutting the tubers into small size and then homogenization using grinding machine, filtering using muslin cloth, sedimentation, decanting (of watery supernatant), sun drying to brittleness and milling (using mills stone) to obtain powdered starch. About $300 \mathrm{~g}$ was the weight of the processed tuber. The powdered starch was stored in air tight containers until required for analysis.

\section{Proximate composition analysis of the powdered starch}

For the determination of the moisture content, crude protein, crude fibre, crude fat, ash, carbohydrate, standard analytical procedures for food analysis described by AOAC [13] was adopted.

\section{Determination of moisture content}

Weight of $2 \mathrm{~g}$ of the sample was put into crucibles, dried in an oven at $105^{\circ} \mathrm{C}$ to a constant weight. The percentage loss in weight was expressed as percentage moisture content on dry weight basis. This was repeated three times to obtain triplicate values.

\section{Protein determination}

Total protein content was determined by the Kjedahl method. A weight of $500 \mathrm{mg}$ of the sample was weighed in triplicate into a Kjedahl flask, About $10 \mathrm{~cm}^{3}$ of concentrated $\mathrm{H}_{2} \mathrm{SO}_{4}$ was added, catalyst mixture ( $1 \mathrm{~g})$ containing sodium sulphate $\left(\mathrm{Na}_{2} \mathrm{SO}_{4}\right)$ copper sulphate $\left(\mathrm{CuSO}_{4}\right)$ and selenium oxide $\left(\mathrm{SeO}_{2}\right)$ in the ratio of 10:5:1 respectively was added to hasten the digestion. Pieces of granulated Zinc or anti-bump granules were added. The sample was then digested in a fume cupboard until the solution became colourless. Distillation was carried out with about $10 \mathrm{~cm}^{3}$ of $40 \% \mathrm{NaOH}$ solution. The condenser tip was dipped into a conical flask containing $5 \mathrm{~cm}^{3}$ of $4 \%$ boric acid in a mixed indicator (containing 5 drops of bromo cresol green methyl red indicator solution) till the boric acid solution turned green. Titration was done in the receiver flask with $0.01 \mathrm{~N} \mathrm{HCl}$ until the solution turned red. The percentage $(\%)$ protein was then calculated.

\section{Determination of crude fibre}

The estimation of the crude fibre was done by acid and alkaline digestion methods. Exactly $2 \mathrm{~g}$ of sample was defatted. The defatted sample was boiled in $200 \mathrm{ml}$ of $1.25 \%$ Tetra Oxo Sulphate (VI) solution under reflux for 30 minutes. After that, the sample was washed with hot water, using a two-fold muslin cloth to trap the particles. The washed sample was transferred quantitatively back to the flask and boiled again in $200 \mathrm{ml}$ of $1.25 \%$ sodium hydroxide solution for 30 minutes, and washed before it was transferred to a weighed porcelain crucible and dried in the oven at $105^{\circ} \mathrm{C}$ for $3 \mathrm{~h}$. After cooling in a desiccator it was re-weighed. The percentage crude fibre was calculated as follows:

$\%$ Crude fibre $=\frac{W_{2}-W_{3}}{W_{1}} \times 100$

Where:

$\mathrm{W}_{1}=$ weight of sample

$\mathrm{W}_{2}=$ weight of sample + crucible

$\mathrm{W}_{3}=$ weight of crucible + ash 


\section{Determination of crude fat}

Crude fat was determined from the powder by solvent extraction method. Two grams $(2 \mathrm{~g})$ of the starch sample was placed in Whatman extraction thimble and plugged with nonabsorbent cotton wool. The fat content of the sample was then extracted with $9 \%$ petroleum ether at $60-80^{\circ} \mathrm{C}$ and transferred into Soxhlet extraction apparatus for $6 \mathrm{~h}$ at condensation rate of 5-6 drops.

\section{Determination of ash content}

About $2 \mathrm{~g}$ of the sample was taken in triplicates and placed in pre-weighed crucibles and ashed in a muffle furnace at $600^{\circ} \mathrm{C}$ for $3 \mathrm{~h}$. The hot crucibles were cooled in a desiccator and weighed. The percentage residual weight was expressed as ash content.

\section{Carbohydrate determination}

The carbohydrate content of the sample was determined by estimation using arithmetic difference. Percentage (\%) Carbohydrate $=100-(\%$ moisture $+\%$ protein $\%$ ash $+\%$ fat content $+\%$ Crude fiber)

\section{Determination of mineral contents}

The mineral elements were determined by the modified methods of [14], where sodium and potassium were determined using Jenway Flame Photometer, while calcium, magnesium, iron, zinc, manganese and copper were determined using Buch Model 205 Atomic Absorption Spectrophotometer. Phosphorus level was determined using phosphovanado molybdate colorimetric techniques on JENWAY 6100 Spectrophotometer, blank (control) was also determined in the same manner.

\section{Determination of tannins}

Modified method of [15] was adopted for the determination of tannins. A weight of $1000 \mathrm{mg}$ of sample was placed into a centrifuge tube containing $2 \mathrm{ml}$ of sterile distilled water. The tube was centrifuged at $2000 \mathrm{rpm}$ for 10 mins. The content was filtered through Whatman filter paper. A volume of $0.5 \mathrm{ml}$ of the supernatant was made up to $1 \mathrm{ml}$ with distilled water. A volume of $0.5 \mathrm{ml}$ Folin Dennis reagent was added and mixed with $2.5 \mathrm{ml}$ of $20 \%$ sodium carbonate solution. The mixture was allowed to stand for $40 \mathrm{mins}$ at room temperature. The absorbance was measured using spectrophotometer.

\section{Determination of phytate}

For the phytate determination, modified method of [16] was used. Ten grams of sample was measured into a beaker and 100 $\mathrm{mL} 0.2 \mathrm{M} \mathrm{HCl}$ was used to soak sample for $3 \mathrm{~h}$ and then filtered through double layer thick filter papers. A volume of $0.5 \mathrm{~mL}$ of extract was pipette into a boiling tube, $1 \mathrm{~mL}$ of ferric solution was added and the tube was covered and heated in a water bath for $30 \mathrm{~min}$. The mixture was cooled in ice for 15 min; it was then allowed to adjust to a room temperature. $2 \mathrm{ml}$ of 2, 2-Bipyridine was added and the absorbance of the mixture was taken at $600 \mathrm{~nm}$ against a blank made up of distilled water. Phytic acid solution concentrations from 0-40 $\mu \mathrm{g} / \mathrm{ml}$ were used as standards.

\section{Determination of oxalate}

The titrimetric method of [17] was used in the determination of oxalate in the samples but with modifications. A weight of $1 \mathrm{~g}$ of the sample was weighed into $100 \mathrm{ml}$ conical flask. About 75 $\mathrm{cm}^{3}$ of $1.5 \mathrm{M} \mathrm{H}_{2} \mathrm{SO}_{4}$ was added and the solution was carefully stirred with a magnetic stirrer for about $1 \mathrm{~h}$ then filtered using Whatman No1 filter paper. A volume of $25 \mathrm{~cm}^{3}$ of the sample filtrate (extract) was then collected and titrated hot $\left(80^{\circ} \mathrm{C}-90^{\circ} \mathrm{C}\right)$ against $0.1 \mathrm{M} \mathrm{KMnO}_{4}$ solution to the point when a faint pink color appeared which persisted for at least 30 seconds. This was repeated twice more and the concentration of oxalate in each sample was obtained.

\section{Determination of hydrogen cyanide}

The cyanogenic glycoside component was determined by alkaline pictrate method of [18] with slight modifications. A weight of $5 \mathrm{~g}$ of the sample was weighed and dissolved in 50 $\mathrm{ml}$ of distilled water in corked conical flasks. The mixtures were allowed to stand throughout the whole night and the filtered. A volume of $1 \mathrm{ml}$ of the sample was taken in a test tube and then $4 \mathrm{mls}$ of alkaline pictrate was added and then heated in a water bath for 15 minutes. After colour development, the absorbance of colour intensity was measured in a spectrophotometer at $490 \mathrm{~nm}$ and was compared with standard cyanide solution.

\section{Determination of alkaloids}

The quantitative determination of alkaloids was carried out by the alkaline precipitation through gravimetric method as described by [17]. A weight of $2 \mathrm{~g}$ of the sample was measured into a beaker and about $20 \mathrm{~cm}^{3}$ of $10 \%$ ethyl acetate was added and was used to soak the sample. The mixture was allowed to stand at room temperature for $4 \mathrm{~h}$. The mixture was filtered through Whatman filter paper no. 40. The filterate (extract) was concentrated by evaporation over a steam bath. For the alkaloids to be precipitated, concentrated ammonia solution was added in drops to the extract until it was in excess. The resulting alkaloid precipitate was recovered by filtration using a previously weighed filter paper. After filtration, the precipitate was washed with $1 \%$ ammonia solution and dried in the oven at $60^{\circ} \mathrm{C}$ for $60 \mathrm{~min}$, after which it was cooled in a desiccator and reweighed. The experiment was repeated two more times and the average was taken. The weight of alkaloids was determined by difference and expressed as a percentage of the weight of the sample analyzed using the expression.

$\%$ Alkaloids $=\frac{w_{2}-w_{1}}{\text { weight of sample }} \times 100$

Where;

$\mathrm{w}_{1}=$ weight of filter paper

$\mathrm{w}_{2}=$ weight of paper+alkaloid precipitated. 
Citation: Ogbonna AI, Adepoju SO, Ogbonna CIC, et al. Root tuber of Tacca leontopetaloides L. (kunze) for food and nutritional security. Microbiology: Current Research 2017;1(1):7-13.

\section{Determination of saponin}

Modified spectrophotometric method of [19] was adopted for the determination of saponin in the sample. A weight of $1 \mathrm{~g}$ of the sample was added to $20 \mathrm{~cm}^{3}$ of $1 \mathrm{M} \mathrm{HCl}$ in a beaker and was boiled for $3 \mathrm{~h}$. After cooling it was filtered and a volume of $50 \mathrm{~cm}^{3}$ of petroleum ether was added to the filterate and the ether layer evaporated to dryness. A volume of $5 \mathrm{~cm}^{3}$ of acetone/ethanol mixture was added to the residue. $0.4 \mathrm{~cm}^{3}$ of each was taken into 3 different test tubes. $6 \mathrm{~cm}^{3}$ of ferrous sulphate reagent was added into each of them followed by 2 $\mathrm{cm}^{3}$ of concentrated $\mathrm{H}_{2} \mathrm{SO}_{4}$. It was thoroughly mixed and after $10 \mathrm{~min}$ the absorbance was taken at $490 \mathrm{~nm}$. Standard saponin was used to establish the calibration curve.

\section{Determination of flavonoids}

The method of [17] was used for flavonoid determination. A weight of $5 \mathrm{~g}$ of the sample was weighed and repeatedly extracted with $100 \mathrm{~cm}^{3}$ of $80 \%$ methanol at room temperature. The mixture was then filtered through filter paper into a 250 $\mathrm{cm}^{3}$ beaker and the filtrate was transferred into a water bath and allowed to evaporate to dryness and weighed. The $\%$ flavonoid was calculated using the formula:

$x=\frac{W_{2}-W_{1}}{W_{3}} \times 100$

Where,

$\mathrm{x}=$ percentage flavonoids,

$\mathrm{w}_{1}=$ weight of empty beaker,

$\mathrm{w}_{2}=$ weight of empty beaker+flavonoid

$\mathrm{w}_{3}=$ weight of sample.

\section{Statistical analysis}

One way analysis of variance (ANOVA) was used to compare means of variables and results were expressed as means of variables.

\section{Results}

The proximate composition analysis of $T$. leontopetaloides revealed the presence of moisture, $8.66 \%$, crude protein, $6.79 \%$, crude fibre, $5.44 \%$, crude fat, $0.51 \%$, ash, $0.41 \%$, and NFE (total carbohydrate), $78.19 \%$ (Table 1).

The elemental analysis of $T$. leontopetaloides indicated presence of some trace elements including sodium, 34.71 $\mathrm{mg} / 100 \mathrm{~g}$, potassium, $40.18 \mathrm{mg} / 100 \mathrm{~g}$, calcium, $0.25 \mathrm{mg} / 100 \mathrm{~g}$, magnesium, $1.40 \mathrm{mg} / 100 \mathrm{~g}$, iron, $1.37 \mathrm{mg} / 100 \mathrm{~g}$, zinc, 1.64 $\mathrm{mg} / 100 \mathrm{~g}$, manganese, $0.72 \mathrm{mg} / 100 \mathrm{~g}$, copper, $0.68 \mathrm{mg} / 100 \mathrm{~g}$ and phosphorus, $0.06 \mathrm{mg} / 100 \mathrm{~g}$ (Table 2).

The results of antinutrient composition of $T$. leontopetaloides revealed the presence of tannins, $2.50 \mathrm{mg} / 100 \mathrm{~g}$, Phytate, 49.77 $\mathrm{mg} / 100 \mathrm{~g}$, oxalate, $15.51 \mathrm{mg} / 100 \mathrm{~g}$, cyanide, $0.18 \mathrm{mg} / 100 \mathrm{~g}$, alkaloids, $42.90 \mathrm{mg} / 100 \mathrm{~g}$, saponins, $14.67 \mathrm{mg} / 100 \mathrm{~g}$ and flavonoids, $1.46 \mathrm{mg} / 100 \mathrm{~g}$ (Table 3 ).

Table 1. Proximate Composition of T. leontopetaloides.

\begin{tabular}{ll}
\hline Parameter & Concentration (\%) \\
\hline Moisture Content & $8.66 \pm 0.01$ \\
\hline Crude Protein & $6.79 \pm 0.02$ \\
\hline Crude Fibre & $5.44 \pm 0.03$ \\
\hline Crude Fat & $0.51 \pm 0.04$ \\
\hline Ash & $0.41 \pm 0.04$ \\
\hline NFE & $78.19 \pm 0.05$ \\
\hline Values represent mean of three replicates (Mean \pm SD) \\
\hline
\end{tabular}

Table 2. Mineral composition of T. leontopetaloides.

\begin{tabular}{ll}
\hline Mineral & Concentration $(\mathbf{m g} / \mathbf{1 0 0} \mathbf{g})$ \\
\hline Sodium (Na) & $34.71 \pm 0.55$ \\
\hline Potassium (K) & $40.18 \pm 0.12$ \\
\hline Calcium (Ca) & $0.25 \pm 0.13$ \\
\hline Magnessium (Mg) & $1.40 \pm 0.01$ \\
\hline Iron (Fe) & $1.37 \pm 0.15$ \\
\hline Zinc (Zn) & $1.64 \pm 0.05$ \\
\hline Manganese (Mn) & $0.72 \pm 0.26$ \\
\hline Copper (Cu) & $0.68 \pm 0.04$ \\
\hline Phosphorous (P) & $0.06 \pm 0.02$ \\
\hline
\end{tabular}

Values represent mean of three replicates (Mean \pm SD)

Table 3. Anti-nutritional composition of T. leontopetaloides.

\begin{tabular}{ll}
\hline Parameter & Concentration $(\mathbf{m g} / \mathbf{1 0 0 g})$ \\
\hline Tannins & $2.50 \pm 0.06$ \\
\hline Phytates & $49.77 \pm 1.09$ \\
\hline Oxalates & $15.51 \pm 0.44$ \\
\hline Cyanides & $0.18 \pm 0.03$ \\
\hline Alkaloids & $42.90 \pm 0.61$ \\
\hline Saponins & $14.67 \pm 0.47$ \\
\hline Flavonoids & $1.46 \pm 0.13$ \\
\hline Values represent mean of three replicates (Mean \pm SD)
\end{tabular}

\section{Discussion}

The results of the analyses of starch of $T$. leontopetaloides showed that it contains important nutrients including minerals and vitamins as well as other phytochemicals that make the plant a good source of food for man and animals.

The proximate composition analysis of $T$. leontopetaloides revealed the presence of moisture, $8.66 \%$, crude protein, 
$6.79 \%$, crude fibre, $5.44 \%$, crude fat, $0.51 \%$, ash, $0.41 \%$, and NFE (total carbohydrate), $78.19 \%$ (Table 1). The results of these findings are in agreement with the findings of [20] who reported moisture, ash, fats, fibre, crude protein and carbohydrate in the range of $10.83 \%, 1.93 \%, 1.06 \%, 4.42 \%$, $6.12 \%$ and $86.07 \%$, respectively in the marc of wild Tacca involucrata. The protein contents of the samples varied from $6.82-9.62 \%$ and are comparably higher than reported values of $5.15 \%$ for white yam, $4.88 \%$ for water yam and $3.64 \%$ for sweet potato [21]. Substantial fibre content, 5.44\% was recorded for the T. leontopetaloides tuber starch. Fibre is very important in food as it helps in alleviating problems associated with constipation by expanding the walls of the colon, absorbs water and provides roughage for the bowels for softer and bulkier stool. It helps reduce the risk of cancers and other bowel diseases as well as reducing the cholesterol levels of the blood [22,23].

The carbohydrate content, $78.19 \%$ (Table 1) obtained from the tuber starch analysis is comparable to the figures recorded by other workers including [20] who recorded $76 \%$ carbohydrate component for $T$. involucrata and Ubwa et al. [20] who recorded $71 \%$ carbohydrate for $T$. leontopetaloides peels. The high carbohydrate observed in the sample shows that it will be a good source of energy required for the daily activities of man.

The mineral composition of $T$. leontopetaloides as shown in Table 2 revealed that it contained some minerals that are of beneficial effect to human and animal bodies. Calcium helps in calcification of bones and its deficiency results to syndromes like rickets [24]. Magnessium helps in phosphate transfer in most reactions, its deficiency results to severe migraine, hypertension, stroke and other disease conditions [25,26]. Zinc is very important for protein and nucleic acid synthesis. Manganese is involved in a number of enzyme systems [27]. Iron is very important in production and building of blood cells and is also needed for transporting haemoglobin and for immune responses [28]. Phosphorus is essential for bone and teeth structures [29].

The present study has confirmed the presence of tannins, cyanides, saponins and flavonoids though in small quantities of 2.50, 0.18, 14.67 and $1.46 \mathrm{mg} / 100 \mathrm{~g}$ respectively. Phytates, oxalates and alkaloids were present in appreciable amounts of 49.77, 15.51 and $42.90 \mathrm{mg} / 100 \mathrm{~g}$ respectively (Table 3). These phytochemicals have been known for their various nutritional, pharmacological and physiological uses to man and animals [22]. Tannins as reported by Nwogu et al. [30] are complex phenolic polymers which can bind to proteins and carbohydrates and results to reduction in digestibility and availability of the macromolecules thereby inhibiting microbial growth. Tannins are known to have astringent properties on the mucous membranes and are used in the treatment of wounds emanating from varicose ulcers and haemorrhoids [31,32].

Cyanogenic glycosides (a-hydroxynitrile glycosides) are derived from the five protein amino acids Valine, Isoleucine, Leucine, Phenylalanine and Tyrosine and from the nonproteinogenic amino acid cyclopentenyl glycine. The function of cyanogenic glycosides in plants is dependent on activation by $\beta$-glucosidases to release toxic volatile $\mathrm{HCN}$ as well as ketones or aldehydes to put off herbivores and pathogen attacks. Cyanide is poisonous because it binds with cytochrome oxidase and stops its action in respiration in the body $[33,34]$. The concentration of hydrogen cyanide obtained from this research work, $0.18 \mathrm{mg} / 100 \mathrm{~g}$ is slightly close to that, $0.16 \mathrm{mg} / 100 \mathrm{~g}$ obtained by Ndouyang et al. [35]. However, Ubwa [22] reported hydrogen cyanide concentration of 43-45 $\mathrm{mg} / \mathrm{kg}$ in the peels of $T$. leontopetaloides. The reduction in the concentration of hydrogen cyanide could be as a result of the stepping in water during processing. Previous works including that of Chikwendu [36] and Ndouyang et al. [35] reported that processing especially soaking reduces hydrogen cyanide content in food substances such as African Yam bean.

Saponins are structurally diverse molecules that are chemically referred to as triterpene and steroid glycosides. They consist of nonpolar aglycones coupled with one or more monosaccharide moieties with detergent, wetting, emulsifying, and foaming properties [37]. Saponins, in high concentrations, impart a bitter taste and astringency in dietary plants. The bitter taste of saponin is the major factor that limits its use. In the past, saponins were recognized as anti-nutrient constituents, due to their adverse effects such as throat-irritating activity. In addition, saponins were found to reduce the bioavailability of nutrients and decrease enzyme activity which affects protein digestibility and inhibition of various digestive enzymes such as trypsin and chymotrypsin [38]. The saponin content of $T$. leontopetaloides was found to be $14.67 \mathrm{mg} / 100 \mathrm{~g}$ (Table 3) as compared with the findings of [35] who reported saponin content of $67.9 \mathrm{mg} / 100 \mathrm{~g}$ in T. leontopetaloides that underwent two steps soaking. Environmental influences and location could account for the differences. Recently, saponins are attracting considerable interest as a result of their beneficial effects in humans. A high saponin diet is known to possess hypocholesterolemic and anti-carcinogenic properties as well as reducing the risk of heart diseases [39].

Flavonoids content of the T. leontopetaloides used in this study was found to be $1.46 \mathrm{mg} / 100 \mathrm{~g}$ (Table 3) and was a little higher than that reported by [35] which was $0.38 \mathrm{mg} / 100 \mathrm{~g}$ for $T$. leontopetaloides after two steps soaking. Flavonoids have been reported to be strong antioxidants. They help in preventing the damage caused by free radicals to human cells. Ubwa et al. [22] reported that they slow the proliferation of cancer cells, thereby mediating in most chronic cancer and diabetes cases. Flavonoids have been shown to be able to affect various biological functions: capillary permeability, cellular secretory processes involved in the inflammatory response and inhibition of enzymes, receptors and carriers [40].

The phytates, oxalates and alkaloids contents of $T$. leontopetaloides used in this study were recorded as 49.77, 15.51 and $42.90 \mathrm{mg} / 100 \mathrm{~g}$ respectively. The phytates contents obtained from this research work are similar to $55.7 \mathrm{mg} / 100 \mathrm{~g}$ obtained by [35]. In the same vein, the oxalates contents were similar to $16.2 \mathrm{mg} / 100 \mathrm{~g}$ total oxalates and $14.0 \mathrm{mg} / 100 \mathrm{~g}$ soluble oxalates also reported by [35]. The authors reported that soaking generally is effective in the reduction of antinutritional components especially phytates and oxalates. The 
Citation: Ogbonna AI, Adepoju SO, Ogbonna CIC, et al. Root tuber of Tacca leontopetaloides L. (kunze) for food and nutritional security. Microbiology: Current Research 2017;1(1):7-13.

soaking of the tubers during processing has been observed to influence the content of the anti-nutrients, thereby presenting the tubers as good sources of food materials. Nwosu [41] reported a significant reduction in phytates, tannins and oxalates contents following soaking which is in agreement with the findings of this research. Phytates and oxalates form complexes with calcium, magnesium, iron, and Zinc and decrease their bioavailability [35].

The values of the phytates, oxalates and alkaloids in the tubers is an indication that utilization of the tubers as food might not have any negative impact that is always connected with utilization of oxalates which is in connection with having negative impact on accessibility of minerals [42].

In general, the anti-nutritional components of $T$. leontopetaloides was considered low with an indication that the tubers can to a great extent be used as food, believing that there would be no interference of the anti-nutrients with the nutrients such as proteins and other minerals in the body.

\section{Conclusion}

Anti-nutritional factors are present in most foods of plant origin and are responsible for the harmful effects which are related to absorption of nutrients that interfere with the normal functioning of certain organs. T. leontopetaloides when eating raw is poisonous and lethal but processing it by soaking in water enhances availability of the micronutrient and aids in the reduction of concentration of the anti-nutritional factors. The anti-nutritional factors and their breakdown products possess beneficial health effects if present in minute amounts. This study has shown that $T$. leontopetaloides when processed properly has the potential of a good food source to man as it contains calcium, iron, potassium and other micronutrients needed for the proper functioning of human body. However, physiological and toxicological effects of the plant need to be investigated.

\section{Acknowledgements}

Authors would like to acknowledge the technical assistance given to them by the technical staff of Biology laboratory of Federal College of Forestry, Jos, led by Mrs J. S. Tanko. We also appreciate the technical staff of Biochemistry laboratory, National Veterinary Research Institute (NVRI) Vom, Plateau State for helping in carrying out the various analyses.

\section{Conflict of Interests}

The authors declare that there is no conflict of interests regarding the publication of this paper.

\section{References}

1. FAO: The State of Food Insecurity in the World. Monitoring the progress towards the world food Summit FAO, Rome Italy 2004.

2. Arora RK, Pandey A. Wild Edible Plants of India, Diversity, Consumation and use. National Bureau of Plant Genetic Resources, New Delhi, India. 1996;294.
3. Edison S, Unnikrishnam M, Vimaku B, et al. Biodiversity of tropical crops in India. NBA scientific Bulletin No. 7 National Biodiversity Authority of India, Tamilnadu, India. 2006;60.

4. Abroumand A, Deokule SS. Proximately and mineral composition of wild coco, (Eulophia Ochreata) (L) tuber in Iron. Asian J Food Agro Ind. 2009;2:203-9.

5. Akubugwo IE, Obasi AN, Ginika SC. Nutritional potential of the leaves and seeds of Black night shade-Solanum nigrum L. var Virginicum from Akikpo-Nigeria. Pak. J Nut. 2007;6:323-6.

6. Aberomand A. Protein, fat, calories, minerals, phytic acid and phenolic in some plant food Based Diet. J Food Proc Tech. 2011;2:104-8.

7. Ujowundu CO, Igwe CU, Enemor VHA, et al. Nutritive and anti-nutritive properties of Boerhavia diffusa and Commelina nudiflora leaves. Pak J Nutr. 2008;7:90-2.

8. Yisa J, Egila JN, Darlinton AO. Chemical composition of Annona senegalensis from Nupe land, Nigeria. Afr J Biotechnol. 2010;9:4106-9.

9. Kay DE. Root crops 2nd edition In: Good my E.G.B. (Ed). Tropical Development and Research Institute, London, UK (now National Resources Institute, UK). 1987;380.

10. Manek RV, Kunle OO, Emeje MO, et al. "Physical, Thermal and Sorption Profile of Starch obtained from Tacca Leontopetaloides”. Starch 2005;57:55-61.

11. Caddick RC, Wilkin P, Rudall PJ,et al. Yams reclassified: A recircumscription of Dioscoreaceae and Dioscoreales. Taxon. 2002;51:103-14.

12. Ukpabi UJ. Cassava processing and utilization. 1st Edition. A sensitization Book. National Root Crop Research Institute, (NRCRI) Umuahia, Nigeria. 2008;1-24

13. AOAC Association of Official Analytical Chemists. Official Methods of Analysis of the AOAC. 15th edn. (Gaithersburg, S. edn)In: Washington DC USA. 2006;78-90.

14. Mathew JT, Ndamitso MM, Otori AA, et al. Inobeme A, Adamu A. Proximate and Mineral Compositions of Seeds of Some Conventional and Non-Conventional Fruits in Niger State, Nigeria. Acad Res. Int. 2014;5:113-8.

15. Pearson D. Chemical Analysis of Foods. 7th Edition, Churchhill Livingstone, London 1976.

16. Markkar HPS, Blummer, Browny NK, et al. Gravimetric analysis of tannins and their correlation with chemical and protein precipitation methods. J Food Sci Agri. 1993;61:161-5.

17. Krishnaiah D, Devi T, Bono A, et al. Studies on phytochemical constituents of six Malaysian medicinal plants. J Med Plants Res. 2009;3:67-72.

18. Onwuka GI. Food analysis and instrumentation theory and practice. Naphthali print, Nigeria. 2005;63-98.

19. Brunner JH. Direct Spectrophotometric determination of Saponin Anal. Chem. 1984;34:1314-26.

20. Bosha JA, Gberinder FA, Asuzu IU. Antihyperglyceamic Effect of Tacca involucrata on Alloxan Induced Diabetic Rats. Ghana Biomedical Convention, Cape Coast. 2013;56. 
21. Alaise C, Linden G. Food Biochemistry. Chapman and Hall. Food Science Book. Aspen publishers Inc, Maryland. 1999;15:21.

22. Ubwa ST, Anhwange BA, Chia JT. Chemical Analysis of Tacca leontopetaloides Peels. Am J Food Tech 2011;6:932-8.

23. Princewill-Ogbonna IL, Ibeji CC. Comparative Study on Nutritional and Anti-nutritional Composition of three Cultivars (red, green and yellow) of Aerial Yam (Dioscorea bulbifera). IOSR J Environ Sci, Toxicol Food Tech. 2015;9:79-86.

24. Dahouervon -Ahoussi E, Adjou ES, Lozes E, et al. Nutritional and microbiological characterization of pulp powder of locust bean (Parkia biglobosa Benth) used as a supplement in infant feeding in Northern Benin. African $\mathbf{J}$ Food Sci. 2012;6:232-8.

25. Appel LJ. Nonpharmacologic therapies that reduce blood pressure: a fresh perspective. Clin Cardiol 1999;22:1-5.

26. Bello MO, Falade OS, Adewusi SRA, et al. Studies on the chemical compositions and antinutrients of some lesser known Nigerian fruits. African J Biotechnol. 2008;7:3972-9.

27. Abara AE. Proximate and Mineral Elements Compositions of the tissue and peel of Dioscorea bulbifera tuber. Pakistan. J Nutr 2011;10:543-51.

28. Trease EC, Evans WC. Pharmacognosy. 16th Edition, W.B. Saunders, Philadelphia, 2009; 365-650.

29. Mason JB. Vitamins, trace minerals and other micronutrients. In: Goldman L, Schafer Al, eds Goldman's Cecil Medicine, 24th edn, Elsevier Saunders Philadelpia PA, United States 2011.

30. Nwogu LA. Igwe CU, Emejulu AA. Effects of Landolphia owariensis leaf extract on the liver function profile and haemoglobin concentration of albino rats. African $\mathrm{J}$ Biotech. 2008;2:240-2.

31. Nguyi AA. "Tannins of some Nigerian flora" Nigerian J Biotech. 1988;6:221-6.

32. Egunyomi A. Moody JO. Eletu, OM. "Antisickling activities of two ethnomedicinal plant recipes used for the management of sickle cell anaemia in Ibadan, Nigeria", African Biotech 2009;8:20-5.

33. Aro SO, Aletor VA, Tewe OO, et al. Preliminary Investigation on the nutrients, antinutrients and mineral composition of microbially fermented cassava starch
34. Proc 33rd Annual Conf Nigeria Society for Animal roduction (NSAP) Ayetoro, Ogun State, Nigeria. 2008;248-51.

35. Golden M. Nutrient requirements of moderately malnourished populations of children. Food Nutr Bull. 2009.

36. Ndouyang CJ, Njintang NY, Facho B, et al. Effect of Processing Method on the Antinutrient Content of Tacca leontopetaloides (L.) Kuntze. Brit J Applied Sci Tech. 2015;5:258-69.

37. Chikwendu NJ. "Production and availability of ground bean (Kerstingiella geocarpa) in a typical Nigerian community: implication for nutrition education and national development”. J Home Eco Res. 2005;6:135-41.

38. Shanthakumari S, Mohan V, Britto J. Nutritional evaluation and elimination of toxic principles in wild yam (Dioscorea spp.). Trop Subtrop Agro-ecosyst. 2008;8: 225-319.

39. Liener IE. Phytohemagglutinins: their nutritional significance. J Agric Food Chem 1974;22:17-22.

40. Habtamu FG, Negussie R. Antinutritional factors in plant foods: Potential health benefits and adverse effects. Int J Nutr Food Sci. 2014;3:284-9.

41. Middleton E. The flavonoids. Trends in Pharmacol Sci. 1984;5:334-8.

42. Nwosu JN. Effects of soaking, blanching and cooking on the antinutritional properties of asparagus bean (Vigna sesquipedalis) flour. Nat Sci. 2010;8:163-7.

43. Onyeike EN, Omubo-Dede TT. Effect of heat treatment on the proximate composition, energy values, and levels of some toxicants in African Yam bean (Sphenostylis stenocarpo) seed varieties. Plan Foods Hum Nutr. 2002;57:223-31.

\section{*Correspondence to}

Ogbonna AI

University of Jos,

Plateau State,

Nigeria

E-mail: ogbonabi@yahoo.co.uk 